\title{
Stereoselective Assembly of a 1,3-Diene via Coupling between an Allenic Acetate and a (B)-alkylborane: Synthetic Studies on Amphidinolide B1.
}

\author{
Amit K. Mandal ${ }^{\mathbb{I}}$, John S. Schneekloth, Jr. ${ }^{\S}$ and Craig M. Crews ${ }^{\S \nsubseteq \# *}$
}

\section{Experimental Procedures and Characterization Data}

General. Unless otherwise indicated, reactions were carried out under a nitrogen atmosphere in flame- or oven-dried glassware using freshly distilled solvents. THF was distilled from sodium/benzophenone. Dichloromethane was distilled from calcium hydride. Triethylamine was distilled from calcium hydride, and stored over potassium hydroxide. Reactions were monitored by thin layer chromatography (TLC) with $0.25-\mathrm{mm}$ E. Merck pre-coated silica gel plates. Silica gel for flash chromatography (particle size 32-63 $\mu \mathrm{m})$ was supplied by Silicycle. Yields refer to chromatographically and spectroscopically pure compounds unless otherwise noted. ${ }^{1} \mathrm{H}$ and ${ }^{13} \mathrm{C}$ spectra were recorded on Bruker Avance DPX-500 or Bruker Avance DPX-400 spectrometers. Chemical shifts are reported as $\delta$ values relative to internal chloroform $\left(\delta 7.24\right.$ for ${ }^{1} \mathrm{H}$ and $\delta 77.0$ for ${ }^{13} \mathrm{C}$ ). Infrared spectra were recorded on a Midac M-1200 FTIR. Optical rotations were measured on a Perkin-Elmer model 341 polarimeter. High resolution mass spectra were measured at the University of Illinois Mass Spectrometry Center. Low resolution mass spectra were acquired on a Waters Micromass ZQ mass Spectrometer.

Compound 8: ${ }^{1} \mathrm{Ipc}_{2} \mathrm{BH}(2.25 \mathrm{~g}, 7.8 \mathrm{mmol})$ in dry $\mathrm{CH}_{2} \mathrm{Cl}_{2}(15 \mathrm{ml})$ was cooled to $0{ }^{\circ} \mathrm{C}$. In another flask, allenyl boronate $(3.24 \mathrm{~g}, 7.8 \mathrm{mmol})$ was dissolved in dry $\mathrm{CH}_{2} \mathrm{Cl}_{2}(15 \mathrm{ml})$ at room temperature. The resulting mixture was added via cannula to the borane and stirred vigorously for $2 \mathrm{~h}$. The borane does not easily go into solution. After $90 \mathrm{~min}$., the reaction was warmed to room temperature until the reaction was homogeneous and then 
recooled to $0{ }^{\circ} \mathrm{C}$ in an ice bath. The ice bath was removed, and the reaction mixture was cooled to $-78{ }^{\circ} \mathrm{C}$. Benzyloxyacetaldehyde $(0.895 \mathrm{ml}, 6.39 \mathrm{mmol})$ was added dropwise and the mixture stirred at $-78{ }^{\circ} \mathrm{C}$ for $2 \mathrm{~h}$. Then distilled acetaldehyde $(0.73 \mathrm{ml}, 13.24$ mmol) was added dropwise and the reaction was stirred for an additional $2 \mathrm{~h}$. The cold bath was removed and the reaction mixture was allowed to warm to room temperature and stirred for an additional $24 \mathrm{~h}$. The reaction was cooled in an ice bath and diluted with $\mathrm{CH}_{2} \mathrm{Cl}_{2}(50 \mathrm{ml})$, followed by addition of $\mathrm{NaOH}(23.2 \mathrm{ml}, 1.0 \mathrm{M}$ aqueous solution) and $\mathrm{H}_{2} \mathrm{O}_{2}(3.0 \mathrm{ml}, 30 \%)$. A thick white precipitate formed. The mixture was stirred for $3 \mathrm{~h}$ at room temperature. It was diluted with $\mathrm{CH}_{2} \mathrm{Cl}_{2}(50 \mathrm{ml})$, aqueous saturated $\mathrm{NaHCO}_{3}$ and brine $(50 \mathrm{ml})$. The biphasic mixture was stirred for $30 \mathrm{~min}$ or until the precipitate has dissolved. The two layers were separated, and the aqueous layer was extracted with $\mathrm{CH}_{2} \mathrm{Cl}_{2}(2 \times 50 \mathrm{ml})$. The organic layers were combined, washed with brine $(1 \mathrm{x} 150 \mathrm{ml})$, dried $\left(\mathrm{Na}_{2} \mathrm{SO}_{4}\right)$, filtered and evaporated under reduced pressure. Purification of the crude product by flash chromatography (65\% EtOAc/hexane) gave $\mathbf{8}$ as a colorless oil (1.43 g, $6.07 \mathrm{mmol}, 95 \%)$.

FT-IR $\quad v_{\max }\left(\right.$ neat, $\left.\mathrm{cm}^{-1}\right)$ 3187-3600.

${ }^{1} \mathbf{H}$ NMR $\delta_{\mathrm{H}}\left(500 \mathrm{MHz} ; \mathrm{CDCl}_{3}\right) 7.26(5 \mathrm{H}, \mathrm{m}), 5.57(1 \mathrm{H}, \mathrm{m}), 5.48(1 \mathrm{H}, \mathrm{t}, J 8.2)$, 4.55 (1 H, m), 4.49 (2 H, s), 3.77 (1 H, m), 3.40 (1 H, dd, J 4.4 and 9.5), $3.35(1 \mathrm{H}, \mathrm{dd}, J 7.4$ and 9.4), $2.25(1 \mathrm{H}, \mathrm{m}), 2.18(1 \mathrm{H}, \mathrm{m})$ and $1.11(3 \mathrm{H}$, $\mathrm{d}, J 6.5)$.

${ }^{13}$ C NMR $\quad \delta_{\mathrm{c}}\left(125.7 \mathrm{MHz} ; \mathrm{CDCl}_{3}\right) 136.74,130.17,128.78,127.45,126.77,72.64$, $72.38,65.93,65.59,36.24$ and 21.87 .

FABHRMS $m / z$ found $237.1490\left(\mathrm{M}^{+}+\mathrm{H}\right) . \mathrm{C}_{14} \mathrm{H}_{20} \mathrm{O}_{3} \mathrm{H}$ requires 237.1491.

$[\alpha]_{\mathrm{D}}^{\mathbf{2 0}} \quad\left(\mathrm{c} 0.30, \mathrm{CHCl}_{3}\right)+30.0$

Compound 9. The diol 8 (506 mg, $2.14 \mathrm{mmol}$ ) was dissolved in dry $\mathrm{CH}_{2} \mathrm{Cl}_{2}(50 \mathrm{ml})$ and cooled to $0{ }^{\circ} \mathrm{C}$. It was treated subsequently with $\mathrm{Na}_{2} \mathrm{HPO}_{4}(912.3 \mathrm{mg}, 6.4 \mathrm{mmol})$ and $m$ CPBA $(1.055 \mathrm{~g}, \sim 77 \%, 4.7 \mathrm{mmol})$. The mixture was stirred at $0{ }^{\circ} \mathrm{C}$ for $30 \mathrm{~min}$., then warmed to r.t. and stirred for $6 \mathrm{~h}$. The reaction was quenched by adding aqueous saturated $\mathrm{NaHCO}_{3}(50 \mathrm{ml})$. It was stirred until organic layer became clear. The two layers were separated, and the aqueous layer was extracted with $\mathrm{CH}_{2} \mathrm{Cl}_{2}(2 \times 50 \mathrm{ml})$. The 
organic layers were combined, washed with brine $(1 \times 100 \mathrm{ml})$, dried $\left(\mathrm{Na}_{2} \mathrm{SO}_{4}\right)$, filtered and evaporated under reduced pressure. Purification of the crude product by flash chromatography (65\% EtOAc/hexane) gave 9 as a colorless oil $(512.9 \mathrm{mg}, 2.03 \mathrm{mmol}$, $95 \%)$.

FT-IR $\quad v_{\max }\left(\right.$ neat, $\left.\mathrm{cm}^{-1}\right)$ 3175-3571.

${ }^{1} \mathbf{H}$ NMR $\quad \delta_{\mathrm{H}}\left(500 \mathrm{MHz} ; \mathrm{CDCl}_{3}\right) 7.34(5 \mathrm{H}, \mathrm{m}), 4.58(2 \mathrm{H}, \mathrm{s}), 4.01(1 \mathrm{H}, \mathrm{m}), 3.76(1$ $\mathrm{H}, \mathrm{m}), 3.58(2 \mathrm{H}, \mathrm{d}, J$ 5.7), $3.22(1 \mathrm{H}, \mathrm{m}), 3.05(1 \mathrm{H}, \mathrm{dd}, J 4.4$ and 7.7$)$, $1.73(1 \mathrm{H}, \mathrm{m}), 1.65(1 \mathrm{H}, \mathrm{m})$ and $1.22(3 \mathrm{H}, \mathrm{d}, J 5.9)$.

${ }^{13}$ C NMR $\quad \delta_{\mathrm{c}}\left(125.7 \mathrm{MHz} ; \mathrm{CDCl}_{3}\right) 137.55,128.48,127.92,73.61,71.37,68.90$, $65.85,58.46,55.15,53.74,37.41$ and 23.99 ,

LRMS $\quad m / z$ (EI) $275.2\left(\mathrm{M}^{+}+\mathrm{Na}, 100 \%\right) . \mathrm{C}_{14} \mathrm{H}_{20} \mathrm{O}_{4} \mathrm{Na}$ requires 275.1.

$[\alpha]_{\mathrm{D}}^{20} \quad\left(\mathrm{c} 0.23, \mathrm{CHCl}_{3}\right)+21.0$

Compound 10: The hydroxyl epoxide $(1.247 \mathrm{~g}, 4.988 \mathrm{mmol})$ was dissolved in dry $\mathrm{CH}_{2} \mathrm{Cl}_{2}(50 \mathrm{ml})$ and cooled to $-78{ }^{\circ} \mathrm{C}$, and subsequently treated with 2,6-lutidine (4.64 $\mathrm{ml}, 39.90 \mathrm{mmol})$ and TBSOTf $(4.55 \mathrm{ml}, 19.95 \mathrm{mmol})$. It was stirred at the same temperature for $1 \mathrm{~h}$. It was quenched with aqueous saturated $\mathrm{NaHCO}_{3}$ solution at $-78{ }^{\circ} \mathrm{C}$, and warmed to room temperature. The two layers were separated, and the aqueous layer was extracted with $\mathrm{CH}_{2} \mathrm{Cl}_{2}(2 \times 40 \mathrm{ml})$. The organic layers were combined, washed with brine $(1 \times 100 \mathrm{ml})$, dried $\left(\mathrm{Na}_{2} \mathrm{SO}_{4}\right)$, filtered and evaporated under reduced pressure. Purification of the crude product by flash chromatography (10\% EtOAc/hexane) gave bis-silylether as a colorless oil (2.28 g, $4.74 \mathrm{mmol}, 95 \%)$.

FT-IR $\quad v_{\max }\left(\right.$ neat, $\left.\mathrm{cm}^{-1}\right) 2925$.

${ }^{1}$ H NMR $\quad \delta_{\mathrm{H}}\left(500 \mathrm{MHz} ; \mathrm{CDCl}_{3}\right) 7.25(5 \mathrm{H}, \mathrm{m}), 4.55(2 \mathrm{H}, \mathrm{s}), 3.95(1 \mathrm{H}, \mathrm{m}), 3.55(1$ $\mathrm{H}, \mathrm{m}), 3.43(2 \mathrm{H}, \mathrm{d}, J 5.3), 3.03(1 \mathrm{H}, \mathrm{m}), 2.86(1 \mathrm{H}, \mathrm{dd}, J 4.5$ and 8.2$)$, 1.76 ( $1 \mathrm{H}$, ddd, $J$ 2.6, 8.2 and 14.4), 1.25 (1 H, ddd, $J$ 4.7, 8.8 and 14.4), $1.10(3 \mathrm{H}, \mathrm{d}, J 6.0), 0.83(9 \mathrm{H}, \mathrm{s}), 0.81(9 \mathrm{H}, \mathrm{s}), 0.01(3 \mathrm{H}, \mathrm{s}), 0.00(3 \mathrm{H}, \mathrm{s})$, $-0.004(3 \mathrm{H}, \mathrm{s})$ and $-0.011(3 \mathrm{H}, \mathrm{s})$.

${ }^{13}$ C NMR $\quad \delta_{\mathrm{c}}\left(125.7 \mathrm{MHz} ; \mathrm{CDCl}_{3}\right) 137.18,128.64,126.53,72.64,71.38,70.57$, $65.94,57.97,53.38,38.11,24.85,22.46,17.13,-4.5$ and -4.7 .

LRMS $\quad m / z$ (EI) $503.5\left(\mathrm{M}^{+}+\mathrm{Na}, 100 \%\right) . \mathrm{C}_{26} \mathrm{H}_{49} \mathrm{O}_{4} \mathrm{Si}_{2} \mathrm{Na}$ requires 503.3. 
$[\alpha]_{\mathbf{D}}^{20} \quad\left(\mathrm{c} 0.33, \mathrm{CHCl}_{3}\right)+6.1$

To a solution of $\mathrm{Me}_{3} \mathrm{Al}(2.49 \mathrm{ml}, 4.99 \mathrm{mmol}, 2.0 \mathrm{M}$ solution in hexane) in dry hexane (30 $\mathrm{ml})$ at room temperature was added methyllithium $(1.55 \mathrm{ml}, 2.49 \mathrm{mmol}, 1.6 \mathrm{M}$ solution in $\mathrm{Et}_{2} \mathrm{O}$ ). The solution was then stirred at the same temperature for $10 \mathrm{~min}$., followed by addition of bis-silylether $(1.615 \mathrm{~g}, 3.33 \mathrm{mmol})$ in dry hexane $(2 \mathrm{ml})$. It was heated to 50 ${ }^{\circ} \mathrm{C}$ for $6 \mathrm{~h}$, cooled to room temperature and quenched with aqueous saturated $\mathrm{NH}_{4} \mathrm{Cl}$ (30 $\mathrm{ml})$. The two layers were separated, and the aqueous layer was extracted with EtOAc ( $2 \mathrm{x}$ $30 \mathrm{ml})$. The organic layers were combined, washed with brine $(1 \mathrm{x} 50 \mathrm{ml})$, dried $\left(\mathrm{Na}_{2} \mathrm{SO}_{4}\right)$, filtered and evaporated under reduced pressure. Purification of the crude product by flash chromatography (gradient $1 \%$, then $3 \%$ to $25 \%$ EtOAc/hexane) gave alcohol as a colorless oil (1.49 g, $2.99 \mathrm{mmol}, 90 \%)$.

FT-IR $\quad v_{\max }\left(\right.$ neat, $\left.\mathrm{cm}^{-1}\right) 3618-3484,2933$.

${ }^{1} \mathbf{H}$ NMR $\delta_{\mathrm{H}}\left(400 \mathrm{MHz} ; \mathrm{CDCl}_{3}\right) 7.35(5 \mathrm{H}, \mathrm{m}), 4.53(2 \mathrm{H}, \mathrm{s}), 3.92(2 \mathrm{H}, \mathrm{m}), 3.52(1$ H, dd, J 5.2 and 9.7), 3.43 (1 H, dd, $J 5.8$ and 9.5), 3.36 (1 H, m), 2.40 (1 H, br s), 1.64 (1 H, m), 1.54 (1 H, m), 1.39 (1 H, m), 1.13 (3 H, d, J 6.2), 0.96 (3 H, d, J 6.4), 0.91 (9 H, s), 0.89 (9 H, s), 0.12 (3 H, s), 0.10 (3 H, s), $0.07(3 \mathrm{H}, \mathrm{s})$ and $0.05(3 \mathrm{H}, \mathrm{s})$.

${ }^{13} \mathbf{C}$ NMR $\quad \delta_{\mathrm{c}}\left(125.7 \mathrm{MHz} ; \mathrm{CDCl}_{3}\right) 137.04,127.31,126.63,73.73,72.38,71.66$, $71.18,65.93,42.94,31.58,24.92,22.48,17.17,13.72,-4.94,-5.33,-5.60$ and -5.81 .

LRMS $\quad m / z(E I) 519.5\left(\mathrm{M}^{+}+\mathrm{Na}, 100 \%\right) . \mathrm{C}_{27} \mathrm{H}_{52} \mathrm{O}_{4} \mathrm{Si}_{2} \mathrm{Na}$ requires 519.3.

$[\alpha]_{\mathrm{D}}{ }^{20} \quad\left(\mathrm{c} 0.33, \mathrm{CHCl}_{3}\right)-6.7$

The alcohol (977 mg, $1.95 \mathrm{mmol})$ was dissolved in dry $\mathrm{CH}_{2} \mathrm{Cl}_{2}(20 \mathrm{ml})$ and cooled to -78 ${ }^{\circ} \mathrm{C}$, and subsequently treated with 2,6-lutidine $(1.81 \mathrm{ml}, 7.80 \mathrm{mmol})$ and TBSOTf (1.78 $\mathrm{ml}, 3.90 \mathrm{mmol})$. It was stirred at the same temperature for $1 \mathrm{~h}$. It was quenched with aqueous saturated $\mathrm{NaHCO}_{3}$ solution at $-78{ }^{\circ} \mathrm{C}$, and warmed to room temperature. The two layers were separated, and the aqueous layer was extracted with $\mathrm{CH}_{2} \mathrm{Cl}_{2}(2 \times 20 \mathrm{ml})$. The organic layers were combined, washed with brine $(1 \times 50 \mathrm{ml})$, dried $\left(\mathrm{Na}_{2} \mathrm{SO}_{4}\right)$, filtered and evaporated under reduced pressure. Purification of the crude product by flash 
chromatography (10\% EtOAc/hexane) gave tris-silylether $\mathbf{1 0}$ as a colorless oil (1.11 g, $1.83 \mathrm{mmol}, 94 \%)$.

FT-IR $\quad v_{\max }\left(\right.$ neat, $\left.\mathrm{cm}^{-1}\right) 2929,1254$.

${ }^{1}$ H NMR $\delta_{\mathrm{H}}\left(400 \mathrm{MHz} ; \mathrm{CDCl}_{3}\right) 7.34(5 \mathrm{H}, \mathrm{m}), 4.54(1 \mathrm{H}, \mathrm{d}, J 12.5), 4.49(1 \mathrm{H}, \mathrm{d}, J$ 12.4), 3.89 (1 H, m), 3.84 (1 H, m), 3.73 (1 H, dd, $J 1.6$ and 9.4), 3.43 (2 H, m), 1.79 (1 H, m), 1.52 (2 H, m), $1.11(3 \mathrm{H}, \mathrm{d}, J$ 5.8), 0.905 (9 H, s), 0.902 (9 H, s), 0.900 (9 H, s), 0.79 (3 H, d, J 6.6), 0.092 (3 H, s), 0.084 (3 $\mathrm{H}, \mathrm{s}), 0.080(3 \mathrm{H}, \mathrm{s}), 0.070(3 \mathrm{H}, \mathrm{s}), 0.066(3 \mathrm{H}, \mathrm{s})$ and $0.062(3 \mathrm{H}, \mathrm{s})$.

${ }^{13}$ C NMR $\delta_{\mathrm{c}}\left(125.7 \mathrm{MHz} ; \mathrm{CDCl}_{3}\right)$

LRMS $\quad m / z(E I) 633.7\left(\mathrm{M}^{+}+\mathrm{Na}, 100 \%\right) . \mathrm{C}_{33} \mathrm{H}_{66} \mathrm{O}_{4} \mathrm{Si}_{3} \mathrm{Na}$ requires 633.4.

$[\alpha]_{\mathbf{D}}^{20} \quad\left(\mathrm{c} 0.16, \mathrm{CHCl}_{3}\right)+9.0$

Fragment 2. A mixture of benzyl ether $10(938 \mathrm{mg}, 1.5 \mathrm{mmol})$ and $20 \% \mathrm{Pd}(\mathrm{OH})_{2}$ on charcoal $(224.97 \mathrm{mg})$ in absolute $\mathrm{EtOH}(30 \mathrm{ml})$ was stirred for $30 \mathrm{~min}$. under hydrogen atmosphere at room temperature. The mixture was filtered through celite and the filtrate evaporated under reduced pressure. The crude product was purified by flash chromatography (40\% EtOAc/hexane) to give primary alcohol alcohol as colorless oil. A mixture of Dess-Martin Periodinane $(1.83 \mathrm{~g}, 4.34 \mathrm{mmol})$ in dry $\mathrm{CH}_{2} \mathrm{Cl}_{2}(15 \mathrm{ml})$ was stirred at room temperature for $15 \mathrm{~min}$. A solution of alcohol $(727 \mathrm{mg}, 1.39 \mathrm{mmol})$ in dry $\mathrm{CH}_{2} \mathrm{Cl}_{2}(5 \mathrm{ml})$ was then added dropwise and the resulting mixture stirred at the same temperature for $45 \mathrm{~min}$. The mixture was the diluted with ether $(20 \mathrm{ml})$ and the resulting white suspension treated with a 1:7 mixture of $\mathrm{NaHCO}_{3} / \mathrm{Na}_{2} \mathrm{~S}_{2} \mathrm{O}_{3}(30 \mathrm{ml})$. Stirring was continued at room temperature until the mixture became clear ( 15 min). The two layers were separated, and the aqueous layer was extracted with $\mathrm{Et}_{2} \mathrm{O}(2 \times 30 \mathrm{ml})$. The organic layers were combined, washed with brine $(1 \times 50 \mathrm{ml})$, dried $\left(\mathrm{Na}_{2} \mathrm{SO}_{4}\right)$, filtered and evaporated under reduced pressure. The crude aldehyde $(521 \mathrm{mg}, 1.0 \mathrm{mmol})$ was taken up in dry THF $(10 \mathrm{ml})$ and cooled to $-78{ }^{\circ} \mathrm{C}$. The mixture was then treated with $\mathrm{MeMgBr}$ $\left(0.83 \mathrm{ml}, 2.5 \mathrm{mmol}, 3.0 \mathrm{M}\right.$ solution in $\left.\mathrm{Et}_{2} \mathrm{O}\right)$ and stirred for $1.5 \mathrm{~h}$. The reaction was quenched with aqueous saturated $\mathrm{NH}_{4} \mathrm{Cl}(15 \mathrm{ml})$, and warmed to room temperature. The two layers were separated, and the aqueous layer was extracted with EtOAc ( 2 x $15 \mathrm{ml})$. The organic layers were combined, washed with brine $(1 \times 30 \mathrm{ml})$, dried $\left(\mathrm{Na}_{2} \mathrm{SO}_{4}\right)$, 
filtered and evaporated under reduced pressure to give secondary alcohol $(\sim 1.0 \mathrm{mmol}$, $\sim 100 \%$ ). A mixture of Dess-Martin Periodinane (655.2 $\mathrm{mg}, 1.56 \mathrm{mmol})$ in dry $\mathrm{CH}_{2} \mathrm{Cl}_{2}$ $(10 \mathrm{ml})$ was stirred at room temperature for $15 \mathrm{~min}$. A solution of alcohol $(1.0 \mathrm{mmol})$ in dry $\mathrm{CH}_{2} \mathrm{Cl}_{2}(5 \mathrm{ml})$ was then added dropwise and the resulting mixture stirred at the same temperature for $1.5 \mathrm{~h}$. The mixture was the diluted with ether $(20 \mathrm{ml})$ and the resulting white suspension treated with a 1:7 mixture of $\mathrm{NaHCO}_{3} / \mathrm{Na}_{2} \mathrm{~S}_{2} \mathrm{O}_{3}(30 \mathrm{ml})$. Stirring was continued at room temperature until the mixture became clear $(\sim 15 \mathrm{~min})$. The two layers were separated, and the aqueous layer was extracted with $\mathrm{Et}_{2} \mathrm{O}(2 \times 25 \mathrm{ml})$. The organic layers were combined, washed with brine $(1 \times 50 \mathrm{ml})$, dried $\left(\mathrm{Na}_{2} \mathrm{SO}_{4}\right)$, filtered and evaporated under reduced pressure. Purification of the crude product by flash chromatography (5\% EtOAc/hexane) gave compound Fragment A (2) as a colorless oil (479.7 mg, $0.9 \mathrm{mmol}, 60 \%$ ).

FT-IR $\quad v_{\max }\left(\right.$ neat, $\left.\mathrm{cm}^{-1}\right) 2933,1728,1258$

${ }^{1} \mathbf{H}$ NMR $\delta_{\mathrm{H}}\left(400 \mathrm{MHz} ; \mathrm{CDCl}_{3}\right) 4.11(1 \mathrm{H}, \mathrm{d}, \mathrm{J} 4.5), 3.80(1 \mathrm{H}, \mathrm{m}), 3.64(1 \mathrm{H}, \mathrm{t}, J$ 4.0), 2.23 (3 H, s), 1.75 (1 H, m), 1.52 (2 H, m), 1.11 (3 H, d, J 5.9), 0.95 (9 H, s), 0.94 (9 H, s), 0.89 (9 H, s), 0.82 (3 H, d, J 6.9), $0.11(3 \mathrm{H}, \mathrm{s}), 0.10$ (3 H, s), 0.06 (3 H, s), 0.07 (6 H, s) and $0.05(3 \mathrm{H}, \mathrm{s})$.

${ }^{13}$ C NMR $\quad \delta_{\mathrm{c}}\left(125.7 \mathrm{MHz} ; \mathrm{CDCl}_{3}\right) 209.68,81.09,79.41,67.61,45.28,32.62,28.59$, $25.91,23.05,18.19,14.78,-3.95,-4.46,-4.53,-4.66,-4.94$.

LRMS $\quad m / z(E I) 555.5\left(\mathrm{M}^{+}+\mathrm{Na}, 30 \%\right) . \mathrm{C}_{27} \mathrm{H}_{60} \mathrm{O}_{5} \mathrm{Si}_{3} \mathrm{Na}$ requires 555.4. $[\alpha]_{\mathrm{D}}^{20} \quad\left(\mathrm{c} 0.22, \mathrm{CHCl}_{3}\right)+9.0$

Compound 15. The alcohol $14(2.37 \mathrm{~g}, 10.60 \mathrm{mmol})$ in dry THF $(100 \mathrm{ml})$ was cooled to $0{ }^{\circ} \mathrm{C}$. Then $\mathrm{BH}_{3}{ }^{\bullet} \mathrm{THF}(26.5 \mathrm{ml}, 26.50 \mathrm{mmol}, 1.0 \mathrm{M}$ solution in THF) was introduced slowly. The mixture was stirred at $0{ }^{\circ} \mathrm{C}$ for $1 \mathrm{~h}$, and then warmed to room temperature over $12 \mathrm{~h}$. It was recooled to $0{ }^{\circ} \mathrm{C}$, and subsequently treated with $\mathrm{NaOH}(8.8 \mathrm{ml}, 26.50$ mmol, 3.0 $\mathrm{M}$ aqueous solution) and $\mathrm{H}_{2} \mathrm{O}_{2}(8.92 \mathrm{ml}, 26.50 \mathrm{mmol}$, aqueous $30 \%)$. The reaction mixture was stirred at room temperature for $2 \mathrm{~h}$ and at $50{ }^{\circ} \mathrm{C}$ for $6 \mathrm{~h}$. Then it was cooled to room temperature, and diluted with aqueous saturated $\mathrm{NH}_{4} \mathrm{Cl}(100 \mathrm{ml})$. The two layers were separated, and the aqueous layer was extracted with EtOAc (2 x $100 \mathrm{ml})$. The organic layers were combined, washed with brine $(1 \times 150 \mathrm{ml})$, dried $\left(\mathrm{Na}_{2} \mathrm{SO}_{4}\right)$, filtered 
and evaporated under reduced pressure. Purification of the crude product by flash chromatography (gradient $30 \%$ to $90 \%$ EtOAc/hexane) gave diol as a colorless oil (1.88 g, $7.84 \mathrm{mmol}, 74 \%)$.

FT-IR $\quad v_{\max }\left(\right.$ neat, $\left.\mathrm{cm}^{-1}\right)$ 3336, 2909.

${ }^{1}$ H NMR $\quad \delta_{\mathrm{H}}\left(500 \mathrm{MHz} ; \mathrm{CDCl}_{3}\right) 7.17(2 \mathrm{H}, \mathrm{d}, J$ 8.6) $6.8(2 \mathrm{H}, \mathrm{d}, J$ 8.6), $4.33(1 \mathrm{H}, \mathrm{d}$, $J$ 11.6), $4.32(1 \mathrm{H}, \mathrm{d}, J 11.6), 3.73(1 \mathrm{H}, \mathrm{m}), 3.72(3 \mathrm{H}, \mathrm{s}), 3.64(1 \mathrm{H}, \mathrm{m})$, $3.60(1 \mathrm{H}, \mathrm{d}, J 11.6), 3.44$ (1 H, d, J 11.6), $2.58(2 \mathrm{H}, \mathrm{br} \mathrm{s}), 1.83(2 \mathrm{H}, \mathrm{m})$, $1.21(3 \mathrm{H}, \mathrm{s})$.

${ }^{13}$ C NMR $\quad \delta_{\mathrm{c}}\left(125.7 \mathrm{MHz} ; \mathrm{CDCl}_{3}\right) 159.22,130.71,129.11,67.99,64.57,58.56$, $55.32,38.86$ and 21.02 .

LRMS $\quad m / z(E I) 263.3\left(\mathrm{M}^{+}+\mathrm{Na}, 100 \%\right) . \mathrm{C}_{13} \mathrm{H}_{20} \mathrm{O}_{4} \mathrm{Na}$ requires 263.1.

$[\alpha]_{\mathbf{D}}{ }^{20} \quad\left(\mathrm{c} 0.20, \mathrm{CHCl}_{3}\right)-3.0$

A mixture of diol $(1.608 \mathrm{~g}, 6.69 \mathrm{mmol})$, imidazole $(716.6 \mathrm{mg}, 10.54 \mathrm{mmol})$ and a catalytic amount DMAP (75 mg, $0.67 \mathrm{mmol})$ was dissolved in dry $\mathrm{CH}_{2} \mathrm{Cl}_{2}(70 \mathrm{ml})$ and cooled to $0{ }^{\circ} \mathrm{C}$. tert-Butyldiphenylsilyl chloride $(1.79 \mathrm{ml}, 7.02 \mathrm{mmol})$ was added and the mixture was stirred overnight. The reaction mixture was quenched with aqueous saturated NaHCO3 $(70 \mathrm{ml})$ and brine $(40 \mathrm{ml})$. The two layers were separated, and the aqueous layer was extracted with EtOAc $(2 \times 100 \mathrm{ml})$. The organic layers were combined, washed with brine $(1 \times 150 \mathrm{ml})$, dried $\left(\mathrm{Na}_{2} \mathrm{SO}_{4}\right)$, filtered and evaporated under reduced pressure. Purification of the crude product by flash chromatography (gradient 10\% to $25 \%$ EtOAc/hexane) gave monosilyl protected alcohol $\mathbf{1 5}$ as a colorless oil (3.04 g, 6.35 mmol, 95\%).

FT-IR $\quad v_{\max }\left(\right.$ neat, $\left.\mathrm{cm}^{-1}\right) 3500-3185$.

${ }^{1}$ H NMR $\quad \delta_{\mathrm{H}}\left(500 \mathrm{MHz} ; \mathrm{CDCl}_{3}\right) 7.78(4 \mathrm{H}, \mathrm{m}), 7.49(6 \mathrm{H}, \mathrm{m}), 7.27(2 \mathrm{H}, \mathrm{d}, J$ 8.6), $6.92(2 \mathrm{H}, \mathrm{d}, J$ 8.6), $4.43(1 \mathrm{H}, \mathrm{d}, J$ 10.5), $4.37(1 \mathrm{H}, \mathrm{d}, J 10.5), 3.96(1 \mathrm{H}$, m), $3.84(3 \mathrm{H}, \mathrm{s}), 3.82(1 \mathrm{H}, \mathrm{m}), 3.70(1 \mathrm{H}, \mathrm{d}, J 11.8), 3.64(1 \mathrm{H}, \mathrm{d}, J 11.8)$, $2.89(1 \mathrm{H}, \mathrm{br} \mathrm{s}), 2.03(2 \mathrm{H}, \mathrm{m}), 1.34(3 \mathrm{H}, \mathrm{s})$ and $1.15(9 \mathrm{H}, \mathrm{s})$. 
${ }^{13} \mathbf{C}$ NMR $\quad \delta_{\mathrm{c}}\left(125.7 \mathrm{MHz} ; \mathrm{CDCl}_{3}\right) 159.06,135.66,133.31,131.30,129.87,129.07$, $127.86,113.86,67.80,63.43,60.16,55.33,53.50,38.63,26.91,21.33$ and 19.15 .

LRMS $\quad m / z$ (EI) $501.5\left(\mathrm{M}^{+}+\mathrm{Na}, 100 \%\right) . \mathrm{C}_{29} \mathrm{H}_{38} \mathrm{O}_{4} \mathrm{SiNa}$ requires 501.2.

$[\alpha]_{\mathbf{D}}{ }^{20} \quad\left(\mathrm{c} 0.30, \mathrm{CHCl}_{3}\right)+10$

Ketone 16. To a solution of oxalyl chloride $(3.70 \mathrm{ml}, 41.73 \mathrm{mmol})$ in $\mathrm{CH}_{2} \mathrm{Cl}_{2}(80 \mathrm{ml})$ was added dropwise DMSO $(3.79 \mathrm{ml}, 51.73 \mathrm{mmol})$ at $-70{ }^{\circ} \mathrm{C}$. After the mixture was stirred for $15 \mathrm{~min}$., alcohol 15 (4.46 g, $9.31 \mathrm{mmol})$ in $\mathrm{CH}_{2} \mathrm{Cl}_{2}(10 \mathrm{ml})$ was introduced. Stirring was continued for another $30 \mathrm{~min}$. After addition of $\mathrm{Et}_{3} \mathrm{~N}(9.36 \mathrm{ml}, 65.8 \mathrm{mmol})$, the mixture was warmed to room temperature over a period of $30 \mathrm{~min}$. Water $(80 \mathrm{ml})$ was added. The two layers were separated, and the aqueous layer was extracted with $\mathrm{Et}_{2} \mathrm{O}$ ( 2 x $80 \mathrm{ml})$. The organic layers were combined, washed with water $(150 \mathrm{ml})$, brine $(1 \times 150$ $\mathrm{ml})$, dried $\left(\mathrm{Na}_{2} \mathrm{SO}_{4}\right)$, filtered and evaporated under reduced pressure. Purification of the crude product by flash chromatography (gradient 10\% EtOAc/hexane) gave aldehyde as a colorless oil $(9.31 \mathrm{mmol}, \sim 100 \%)$. It was taken up in $\mathrm{Et}_{2} \mathrm{O}(80 \mathrm{ml})$ and cooled to $-78{ }^{\circ} \mathrm{C}$. $\mathrm{MeMgBr}\left(10.07 \mathrm{ml}, 16.12 \mathrm{mmol}, 1.6 \mathrm{M}\right.$ solution in $\mathrm{Et}_{2} \mathrm{O}$ ) was added dropwise, followed by slow warming to $0{ }^{\circ} \mathrm{C}$ over $40 \mathrm{~min}$. The reaction was quenched with aqueous saturated $\mathrm{NH}_{4} \mathrm{Cl}$ (15 ml), and warmed to room temperature. The two layers were separated, and the aqueous layer was extracted with EtOAc $(2 \times 15 \mathrm{ml})$. The organic layers were combined, washed with brine $(1 \times 30 \mathrm{ml})$, dried $\left(\mathrm{Na}_{2} \mathrm{SO}_{4}\right)$, filtered and evaporated under reduced pressure to give secondary alcohol $(8.06 \mathrm{mmol}, 86 \%)$. To a solution of oxalyl chloride (3.15 ml, $36.11 \mathrm{mmol})$ in $\mathrm{CH}_{2} \mathrm{Cl}_{2}(60 \mathrm{ml})$ was added dropwise DMSO (3.3 ml, 45.91 mmol) at $-70{ }^{\circ} \mathrm{C}$. After the mixture was stirred for $15 \mathrm{~min}$., diastereomeric alcohols (4.0 $\mathrm{g}, 8.06 \mathrm{mmol})$ in $\mathrm{CH}_{2} \mathrm{Cl}_{2}(20 \mathrm{ml})$ was introduced. Stirring was continued for another 30 min. while the bath temperature was warmed from $-70{ }^{\circ} \mathrm{C}$ to $-30{ }^{\circ} \mathrm{C}$. After addition of $\mathrm{Et}_{3} \mathrm{~N}(8.2 \mathrm{ml}, 57.96 \mathrm{mmol})$, the mixture was warmed to room temperature over a period of $10 \mathrm{~min}$. Water $(80 \mathrm{ml})$ was added. The two layers were separated, and the aqueous layer was extracted with $\mathrm{Et}_{2} \mathrm{O}(2 \times 80 \mathrm{ml})$. The organic layers were combined, washed with water $(150 \mathrm{ml})$, brine $(1 \times 150 \mathrm{ml})$, dried $\left(\mathrm{Na}_{2} \mathrm{SO}_{4}\right)$, filtered and evaporated under reduced pressure. Purification of the crude product by flash chromatography (gradient $10 \%$ EtOAc/hexane) gave ketone $\mathbf{1 6}$ as a colorless oil (2.86 g, $6.04 \mathrm{mmol}, 75 \%)$ 
FT-IR $\quad v_{\max }\left(\right.$ neat, $\left.\mathrm{cm}^{-1}\right) 2253,1713$.

${ }^{1} \mathbf{H}$ NMR $\delta_{\mathrm{H}}\left(500 \mathrm{MHz} ; \mathrm{CDCl}_{3}\right) 7.71(4 \mathrm{H}, \mathrm{m}), 7.42(6 \mathrm{H}, \mathrm{m}), 7.23(2 \mathrm{H}, \mathrm{d}, J 8.7)$, $6.91(2 \mathrm{H}, \mathrm{d}, J$ 8.7), 4.30 (1 H, d, J 11.0), 4.26 (1 H, d, J 10.8), 3.84 (3 H, s), $3.76(2 \mathrm{H}, \mathrm{m}), 2.26(3 \mathrm{H}, \mathrm{s}), 2.17(1 \mathrm{H}, \mathrm{m}), 2.09(1 \mathrm{H}, \mathrm{m}), 1.39(3 \mathrm{H}, \mathrm{s})$ and $1.08(9 \mathrm{H}, \mathrm{s})$.

${ }^{13}$ C NMR $\quad \delta_{\mathrm{c}}\left(125.7 \mathrm{MHz} ; \mathrm{CDCl}_{3}\right) 212.57,159.50,136.04,134.00,130.91,130.09$, $129.16,128.11,114.24,83.54,65.69,59.95,55.72,53.87,39.61,27.23$, 25.52, 20.97 and 19.52 .

LRMS $\quad m / z(E I) 513.5\left(\mathrm{M}^{+}+\mathrm{Na}, 40 \%\right) . \mathrm{C}_{30} \mathrm{H}_{38} \mathrm{O}_{4} \mathrm{SiNa}$ requires 513.2.

$[\alpha]_{\mathbf{D}}^{20} \quad\left(\mathrm{c} 0.30, \mathrm{CHCl}_{3}\right)+7.0$

Allenic acetate 18. The ketone (40 mg, $0.08 \mathrm{mmol})$ was dissolved in $\mathrm{Et}_{2} \mathrm{O}(1 \mathrm{ml})$. Ethylnylmagnesium bromide $(0.8 \mathrm{ml}, 0.40 \mathrm{mmol}, 0.5 \mathrm{M}$ solution in THF) was then slowly introduced. After the reaction mixture was heated to reflux for $45 \mathrm{~min}$., it was cooled to room temperature. The reaction was quenched with aqueous saturated $\mathrm{NH}_{4} \mathrm{Cl}(2$ $\mathrm{ml})$. The two layers were separated, and the aqueous layer was extracted with EtOAc ( $2 \mathrm{x}$ $3 \mathrm{ml})$. The organic layers were combined, washed with brine $(1 \times 5 \mathrm{ml})$, dried $\left(\mathrm{Na}_{2} \mathrm{SO}_{4}\right)$, filtered and evaporated under reduced pressure. Purification of the crude product by flash chromatography (25\% EtOAc/hexane) gave ethynyl carbinol as a colorless oil (36.7 mg, $0.07 \mathrm{mmol}, 89 \%$ ) as a 9:1 diastereoisomeric mixture.

FT-IR $\quad v_{\max }\left(\right.$ neat, $\left.\mathrm{cm}^{-1}\right) 3293,2929$.

${ }^{1} \mathbf{H}$ NMR $\delta_{\mathrm{H}}\left(500 \mathrm{MHz} ; \mathrm{CDCl}_{3}\right) 7.71(4 \mathrm{H}, \mathrm{m}), 7.43(6 \mathrm{H}, \mathrm{m}), 7.19(2 \mathrm{H}, \mathrm{d}, J$ 8.6), 6.86 (2 H, d, J 8.8), 4.58 (1 H, d, J 10.7), 4.41 (2 H, d, J 10.7), 3.91 (2 H, obs. m), $3.85(3 \mathrm{H}, \mathrm{s}), 2.48(1 \mathrm{H}, \mathrm{s}), 2.12(1 \mathrm{H}, \mathrm{m}), 2.05(1 \mathrm{H}, \mathrm{m}), 1.47$ (3 $\mathrm{H}, \mathrm{s})$ and $1.09(9 \mathrm{H}, \mathrm{s})$.

${ }^{13}$ C NMR $\quad \delta_{\mathrm{c}}\left(125.7 \mathrm{MHz} ; \mathrm{CDCl}_{3}\right) 159.30,136.03,135.99,135.95,131.64,130.11$, $129.15,128.29,114.09,80.81,73.92,92.78,68.37,65.43,61.02,55.67$, $38.15,27.23,24.83,19.50$ and 18.95 .

LRMS $\quad m / z(E I) 539.5\left(\mathrm{M}^{+}+\mathrm{Na}, 100 \%\right) . \mathrm{C}_{32} \mathrm{H}_{40} \mathrm{O}_{4} \mathrm{SiNa}$ requires 539.3.

$[\alpha]_{\mathrm{D}}^{20} \quad\left(\mathrm{c} 0.16, \mathrm{CHCl}_{3}\right)+5.0$ 
Ethynyl carbinol (2.26 g, $4.27 \mathrm{mmol})$, paraformaldehyde (762.6 mg, $25.40 \mathrm{mmol})$, cuprous bromide (305 mg, $2.14 \mathrm{mmol})$, and diisopropylamine (0.72 ml, $5.10 \mathrm{mmol})$ were refluxed in dry dioxane $(40 \mathrm{ml})$ for $48 \mathrm{~h}$. The dioxane was carefully evaporated, and water $(50 \mathrm{ml})$ was added to the residue. The two layers were separated, and the aqueous layer was extracted with $\mathrm{Et}_{2} \mathrm{O}(2 \times 30 \mathrm{ml})$. The organic layers were combined, washed with brine $(1 \times 50 \mathrm{ml})$, dried $\left(\mathrm{Na}_{2} \mathrm{SO}_{4}\right)$, filtered and evaporated under reduced pressure. Purification of the crude product by flash chromatography (25\% EtOAc/hexane) gave allenic alcohol 17 as a colorless oil (1.59 g, $2.99 \mathrm{mmol}, 70 \%)$.

FT-IR $\quad v_{\max }\left(\right.$ neat, $\left.\mathrm{cm}^{-1}\right) 3410,2925,1955$.

${ }^{1}$ H NMR $\delta_{\mathrm{H}}\left(500 \mathrm{MHz} ; \mathrm{CDCl}_{3}\right) 7.62(4 \mathrm{H}, \mathrm{m}), 7.32(6 \mathrm{H}, \mathrm{m}), 7.06(2 \mathrm{H}, \mathrm{d}, J$ 8.6), $6.77(2 \mathrm{H}, \mathrm{d}, J$ 8.6), 5.39 (1 H, t, $J$ 6.5), $4.73(2 \mathrm{H}, \mathrm{m}), 4.31(1 \mathrm{H}, \mathrm{d}, J$ 10.7), 4.23 (2 H, d, J 10.7), 3.86 (1 H, m), 3.75 (3 H, s), 3.70 (1 H, m), $3.08(1 \mathrm{H}, \mathrm{s}), 1.97(2 \mathrm{H}, \mathrm{m}), 1.22(3 \mathrm{H}, \mathrm{s}), 1.20(3 \mathrm{H}, \mathrm{s})$ and $1.05(9 \mathrm{H}, \mathrm{s})$.

${ }^{13}$ C NMR $\quad \delta_{\mathrm{c}}\left(125.7 \mathrm{MHz} ; \mathrm{CDCl}_{3}\right) 212.55,159.76,135.98,133.96,130.88,130.07$, $129.45,128.28,114.43,83.52,65.66,59.93,55.70,53.84,39.58,27.29$, 25.49, 20.94 and 19.60.

LRMS $\quad m / z(E I) 553.6\left(\mathrm{M}^{+}+\mathrm{Na}, 100 \%\right) . \mathrm{C}_{33} \mathrm{H}_{42} \mathrm{O}_{4} \mathrm{SiNa}$ requires 553.3.

$[\alpha]_{\mathrm{D}}^{20} \quad\left(\mathrm{c} 0.15, \mathrm{CHCl}_{3}\right)+11.0$

The allenic alcohol $(1.2 \mathrm{~g}, 2.28 \mathrm{mmol})$ was treated with $\mathrm{Ac}_{2} \mathrm{O}(10 \mathrm{ml})$ and pyridine $(1 \mathrm{ml})$ and 4-pyrrolidinopyridine $(506 \mathrm{mg}$ ) at room temperature. After the reaction mixture was heated to $40{ }^{\circ} \mathrm{C}$ for $4 \mathrm{~h}$, it was cooled to $0{ }^{\circ} \mathrm{C}$. $\mathrm{MeOH}(5 \mathrm{ml})$ was added and the mixture was stirred at $0{ }^{\circ} \mathrm{C}$ for $5 \mathrm{~min}$. and at room temperature for $30 \mathrm{~min}$. Then $\mathrm{MeOH}$ was removed under reduced pressure. The residue was taken up in $\mathrm{Et}_{2} \mathrm{O}(30 \mathrm{ml})$ and saturated aqueous $\mathrm{NaHCO}_{3}(30 \mathrm{ml})$ was added. The two layers were separated, and the aqueous layer was extracted with $\mathrm{Et}_{2} \mathrm{O}(2 \times 30 \mathrm{ml})$. The organic layers were combined, washed with brine $(1 \times 50 \mathrm{ml})$, dried $\left(\mathrm{Na}_{2} \mathrm{SO}_{4}\right)$, filtered and evaporated under reduced pressure. Purification of the crude product by flash chromatography (5\% EtOAc/hexane) gave allenic acetate 17 as a colorless oil (653 mg, $1.14 \mathrm{mmol}, 50 \%$ ).

FT-IR $\quad v_{\max }\left(\right.$ neat, $\left.\mathrm{cm}^{-1}\right) 2933,1958,1763,1724$. 
${ }^{1}$ H NMR $\delta_{\mathrm{H}}\left(500 \mathrm{MHz} ; \mathrm{CDCl}_{3}\right) 7.58(4 \mathrm{H}, \mathrm{m}), 7.30(6 \mathrm{H}, \mathrm{m}), 7.02(2 \mathrm{H}, \mathrm{d}, J$ 8.6), $6.73(2 \mathrm{H}, \mathrm{d}, J$ 8.6), $5.24(1 \mathrm{H}, \mathrm{t}, J 6.8), 4.82(1 \mathrm{H}, \mathrm{dd}, J 6.7$ and 11.0), 4.73 $(1 \mathrm{H}, \mathrm{dd}, J 7$ and 11.0), 4.36 (1 H, d, $J 11.0), 4.33(1 \mathrm{H}, \mathrm{d}, J 10.8), 3.79$ (2 H, m), $3.72(3 \mathrm{H}, \mathrm{s}), 2.23(3 \mathrm{H}, \mathrm{d}, J$ 0.9), $2.10(3 \mathrm{H}, \mathrm{s}), 1.98(1 \mathrm{H}, \mathrm{m}), 1.82$ $(1 \mathrm{H}, \mathrm{m}), 1.19(3 \mathrm{H}, \mathrm{s})$ and $0.97(9 \mathrm{H}, \mathrm{s})$.

${ }^{13}$ C NMR $\quad \delta_{\mathrm{c}}\left(125.7 \mathrm{MHz} ; \mathrm{CDCl}_{3}\right) 207.85,168.11,164.16,158.76,135.61,133.97$, $131.73,129.58,128.60,127.65,113.65,110.99,93.79,87.00,81.09$, $77.95,65.63,60.61,55.29,26.92,21.14,19.15,18.53$ and 18.00 .

$[\alpha]_{\mathbf{D}}{ }^{20} \quad\left(\mathrm{c} 0.12, \mathrm{CHCl}_{3}\right)+15.0$

Fragment 3. Acetic acid $(0.3 \mathrm{ml})$ was added to the allenic acetate $(8 \mathrm{mg}, 0.014 \mathrm{mmol})$ and LiI $(5.2 \mathrm{mg}, 0.038 \mathrm{mmol})$. The solution was stirred for $40{ }^{\circ} \mathrm{C}$ for $30 \mathrm{~min}$. Water $(0.5$ $\mathrm{ml})$ and hexane $(0.5 \mathrm{ml})$ was added, and the aqueous layer was extracted with hexane $(2 \mathrm{x}$ $1 \mathrm{ml})$. The organic layers were combined, washed with brine $(1 \times 5 \mathrm{ml})$, dried $\left(\mathrm{Na}_{2} \mathrm{SO}_{4}\right)$, filtered (drying and filtration was performed in the dark) and evaporated under reduced pressure. Purification of the crude product by flash chromatography (silica column was neutralized by running 10:20:70 Et 3 N-EtOAc-Hexane, 3\% EtOAc/hexane) gave iodide Fragment B (3) as a colorless oil ( $8.3 \mathrm{mg}, 0.013 \mathrm{mmol}, 96 \%)$.

FT-IR $\quad v_{\max }$

${ }^{1}$ H NMR $\quad \delta_{\mathrm{H}}\left(400 \mathrm{MHz} ; \mathrm{CDCl}_{3}\right) 7.68(4 \mathrm{H}, \mathrm{m}), 7.41(6 \mathrm{H}, \mathrm{m}), 7.18(2 \mathrm{H}, \mathrm{d}, J$ 8.7), $6.86(2 \mathrm{H}, \mathrm{d}, J$ 8.7), $6.09(1 \mathrm{H}, \mathrm{br} \mathrm{s}), 5.94(1 \mathrm{H}, \mathrm{s}), 5.87(1 \mathrm{H}, \mathrm{s}), 4.19(1 \mathrm{H}$, d, $J$ 10.9), $4.05(1 \mathrm{H}, \mathrm{d}, J 11.1), 3.81(3 \mathrm{H}, \mathrm{s}), 3.70(2 \mathrm{H}, \mathrm{m}), 2.01(2 \mathrm{H}, \mathrm{m})$, $1.71(3 \mathrm{H}, \mathrm{d}, J \mathrm{0.4}), 1.37(3 \mathrm{H}, \mathrm{s})$ and $1.06(9 \mathrm{H}, \mathrm{s})$.

MALDI $\quad m / z 663.4086\left(\mathrm{M}^{+}+\mathrm{Na}, 100 \%\right) . \mathrm{C}_{33} \mathrm{H}_{41} \mathrm{IO}_{3} \mathrm{SiNa}$ requires 663.1760.

Compound 21. To a solution of alcohol $20(1.950 \mathrm{~g}, 12.34 \mathrm{mmol})$ in dry $\mathrm{CH}_{2} \mathrm{Cl}_{2}(60 \mathrm{ml})$ was added imidazole $(3.850 \mathrm{~g}, 49.36 \mathrm{mmol})$ and tert-butyldimethylsilyl chloride $(3.702 \mathrm{~g}$, $24.68 \mathrm{mmol}$ ) at room temperature. The reaction mixture was stirred for $2 \mathrm{~h}$, after which it was quenched with aqueous saturated $\mathrm{NH}_{4} \mathrm{Cl}(60 \mathrm{ml})$. The aqueous layer was extracted three times with $\mathrm{CH}_{2} \mathrm{Cl}_{2}(2 \times 50 \mathrm{ml})$. The organic layers were combined, washed with brine, dried $\left(\mathrm{Na}_{2} \mathrm{SO}_{4}\right)$, filtered and evaporated under reduced pressure. The residue was 
purified by flash chromatography to afford silyl ether $(3.156 \mathrm{~g}, 94 \%)$ as a clear colorless oil.

FT-IR $\quad v_{\max }\left(\right.$ neat, $\left.\mathrm{cm}^{-1}\right) 2930,2858,1756$.

${ }^{1} \mathbf{H}$ NMR $\quad \delta_{\mathrm{H}}\left(500 \mathrm{MHz} ; \mathrm{CDCl}_{3}\right) 4.76(1 \mathrm{H}, \mathrm{s}), 4.72(1 \mathrm{H}, \mathrm{s}), 4.26(1 \mathrm{H}, \mathrm{dd}, J 5.7$ and 7.6), 4.13 (2 H, m), 2.37 (1 H, d, J 5.7), 2.36 (1 H, d, J 7.6), 1.72 (3 H, s), $1.22(3 \mathrm{H}, \mathrm{t}, J 6.3), 0.84(9 \mathrm{H}, \mathrm{s}), 0.024(3 \mathrm{H}, \mathrm{s})$ and $0.00(3 \mathrm{H}, \mathrm{s})$.

${ }^{13}$ C NMR $\quad \delta_{\mathrm{c}}\left(125 \mathrm{MHz} ; \mathrm{CDCl}_{3}\right) 173.75,141.49,114.31,71.90,61.05,43.94,26.02$, $23.02,18.65,14.56,-4.63$ and -4.95 .

FABHRMS $[\mathrm{M}+1]^{+}$calculated for $\mathrm{C}_{14} \mathrm{H}_{28} \mathrm{O}_{3} \mathrm{Si}: 273.1808$, observed: 273.1888 $[\alpha]_{\mathrm{D}}{ }^{20} \quad\left(\mathrm{c} 0.54, \mathrm{CHCl}_{3}\right)+13.6$

To a solution of ester $(1.885 \mathrm{~g}, 6.91 \mathrm{mmol})$ in $\operatorname{THF}(69 \mathrm{ml})$ was added $(N, O)$ dimethylhydroxylamine hydrochloride $(1.417 \mathrm{~g}, 14.53 \mathrm{mmol})$. The slurry was cooled to 0 ${ }^{\circ} \mathrm{C}$, and ${ }^{\mathrm{i}} \mathrm{PrMgCl}(13.83 \mathrm{ml}, 27.66 \mathrm{mmol}, 2.0 \mathrm{M}$ solution) was added dropwise. The reaction was stirred for $1 \mathrm{~h}$ at $0{ }^{\circ} \mathrm{C}$, after which it was quenched with aqueous saturated $\mathrm{NH}_{4} \mathrm{Cl}(60 \mathrm{ml})$. EtOAc $(50 \mathrm{ml})$ was added and stirred for $3 \mathrm{~h}$. The aqueous layer was extracted with EtOAc ( $3 \times 50 \mathrm{ml})$, and combined organic layers were washed with brine $(100 \mathrm{ml})$, dried $\left(\mathrm{Na}_{2} \mathrm{SO}_{4}\right)$, filtered and evaporated under reduced pressure. The residue was purified by flash chromatography to afford $21(1.825 \mathrm{~g}, 92 \%)$ as a clear colorless oil. FT-IR $\quad v_{\max }\left(\right.$ neat, $\left.\mathrm{cm}^{-1}\right) 2929,2856,1624$.

${ }^{1}$ H NMR $\delta_{\mathrm{H}}\left(400 \mathrm{MHz} ; \mathrm{CDCl}_{3}\right) 4.75(1, \mathrm{H}, \mathrm{s}), 4.71(1 \mathrm{H}, \mathrm{s}), 4.59(1 \mathrm{H}, \mathrm{brs}), 3.64$ (3 H, s), 3.12 (3 H, brs), 2.29 (1 H, d, J 4.0), 2.28 (1 H, d, J 7.0), 1.707 (3 H, s), $0.815(9 \mathrm{H}, \mathrm{s}), 0.00(3 \mathrm{H}, \mathrm{s})$ and $-0.02(3 \mathrm{H}, \mathrm{s})$.

${ }^{13} \mathbf{C ~ N M R} \quad \delta_{\mathrm{c}}\left(125 \mathrm{MHz} ; \mathrm{CDCl}_{3}\right) 141.88,114.16,70.23,61.57,43.39,26.16,23.15$, $18.74,-4.38$ and -4.90 .

FABHRMS $[\mathrm{M}+1]^{+}$calculated for $\mathrm{C}_{14} \mathrm{H}_{29} \mathrm{NO}_{3} \mathrm{Si}: 288.1995$, observed: 288.1988. $[\alpha]_{\mathbf{D}}{ }^{20} \quad\left(\right.$ c $\left.0.32, \mathrm{CHCl}_{3}\right)+5.2$

Vinyl iodide 23. A solution of alcohol $22(750 \mathrm{mg}, 3.34 \mathrm{mmol})$ in DMF (20 ml) was cooled to $0{ }^{\circ} \mathrm{C}$ and treated with $\mathrm{NaH}(172 \mathrm{mg}, 2.15 \mathrm{mmol})$. After stirring for 30 minutes, 
${ }^{\mathrm{n}} \mathrm{Bu}_{4} \mathrm{NI}(61 \mathrm{mg}, 0.17 \mathrm{mmol})$ and $p$-methoxybenzyl chloride $(1.048 \mathrm{~g}, 6.69 \mathrm{mmol})$ were added. The reaction was warmed to room temperature and stirred for $12 \mathrm{~h}$. The reaction was quenched by adding water $(20 \mathrm{ml})$. EtOAc $(30 \mathrm{ml})$ was added. The aqueous layer was extracted with EtOAc $(3 \times 20 \mathrm{ml})$, and the organic layers were combined, washed with brine $(50 \mathrm{ml})$, dried $\left(\mathrm{Na}_{2} \mathrm{SO}_{4}\right)$, filtered and evaporated under reduced pressure. The residue was purified by flash chromatography to afford 23 (776 $\mathrm{mg}, 70 \%)$ as a clear colorless oil.

FT-IR $\quad v_{\max }\left(\right.$ neat, $\left.\mathrm{cm}^{-1}\right) 2934,2852$.

${ }^{1} \mathbf{H}$ NMR $\delta_{\mathrm{H}}\left(500 \mathrm{MHz} ; \mathrm{CDCl}_{3}\right) 7.09(2 \mathrm{H}, \mathrm{d}, J$ 7.8), $6.72(2 \mathrm{H}, \mathrm{d}, J$ 7.8), $6.33(1 \mathrm{H}$, dt, $J 7.2$ and 14.4), 5.80 (1 H, d, J 14.4), 4.25 (2 H, s), $3.64(3 \mathrm{H}, \mathrm{s}), 3.27$ (2 H, t, J 6.4), $1.98(2 \mathrm{H}, \mathrm{q}, J$ 7.2) and $1.57(2 \mathrm{H}, \mathrm{m})$.

${ }^{13} \mathbf{C ~ N M R} \quad \delta_{\mathrm{c}}\left(125 \mathrm{MHz} ; \mathrm{CDCl}_{3}\right) 159.59,146.29,131.12,129.68,114.43,75.34$, $72.76,69.11,55.69,33.13$ and 28.81 .

FABHRMS $[\mathrm{M}+\mathrm{Na}]^{+}$calculated for $\mathrm{C}_{13} \mathrm{H}_{17} \mathrm{IO}_{2}$ : 355.0171, observed: 355.0166 .

$\alpha, \beta$-unsaturated ketone 24. A flame dried $25 \mathrm{ml}$ round bottom flask was charged with a solution of iodide $23(25 \mathrm{mg}, 0.08 \mathrm{mmol})$ in anhydrous THF $(0.8 \mathrm{ml})$ and cooled to -78 ${ }^{\circ} \mathrm{C}$. ${ }^{\mathrm{t}} \mathrm{BuLi}(97 \mu \mathrm{l}, 1.7 \mathrm{M}$ solution in pentane) was added dropwise. After stirring for 30 min., a solution of Weinreb amide 21 (24 mg, $0.082 \mathrm{mmol}$ ) in THF (1 ml) was introduced slowly. The reaction mixture was stirred for $30 \mathrm{~min}$. at $-78{ }^{\circ} \mathrm{C}$, after which it was warmed to $0{ }^{\circ} \mathrm{C}$ and stirred for $2 \mathrm{~h}$. The reaction was quenched with aqueous saturated $\mathrm{NH}_{4} \mathrm{Cl}(2 \mathrm{ml})$. EtOAc $(2 \mathrm{ml})$ was added. The aqueous layer was extracted with EtOAc (2 x $2 \mathrm{ml})$. The combined organic layers were washed with water $(5 \mathrm{ml})$ and brine $(5 \mathrm{ml})$, dried $\left(\mathrm{Na}_{2} \mathrm{SO}_{4}\right)$, filtered and evaporated under reduced pressure. The residue was purified by flash chromatography to afford ketone $\mathbf{2 4}(28 \mathrm{mg}, 86 \%)$ as a clear colorless oil.

FT-IR $\quad v_{\max }\left(\right.$ neat, $\left.\mathrm{cm}^{-1}\right) 2931,2856,1685$.

${ }^{1} \mathbf{H}$ NMR $\delta_{\mathrm{H}}\left(400 \mathrm{MHz} ; \mathrm{CDCl}_{3}\right) 7.22(2 \mathrm{H}, \mathrm{d}, J$ 8.6), $6.98(1 \mathrm{H}, \mathrm{dt}, J 7.2$ and 15.7), 6.85 (2 H, d, J 8.6), 6.54, (1 H, d, J 15.7), 4.78 (1 H, s), 4.70 (1 H, s), 4.40 (3 H, s), $4.18(1 \mathrm{H}, \mathrm{dd}, J 7.9$ and 5.0), $3.77(3 \mathrm{H}, \mathrm{s}), 3.43(2 \mathrm{H}, \mathrm{t}, J$ 6.2), $2.27(4 \mathrm{H}, \mathrm{m}), 1.74(2 \mathrm{H}, \mathrm{m}), 1.72(3 \mathrm{H}, \mathrm{s}), 0.87(9 \mathrm{H}, \mathrm{s}), 0.00(3 \mathrm{H}, \mathrm{s})$ and $-0.03(3 \mathrm{H}, \mathrm{s})$. 
${ }^{13}$ C NMR $\quad \delta_{\mathrm{c}}\left(125 \mathrm{MHz} ; \mathrm{CDCl}_{3}\right) 201.13,159.22,148.20,140.81,130.49,129.26$, $124.80,114.23,113.83,72.69,69.13,55.29,43.61,29.44,28.24,25.77$, $22.74,18.20,-4.68$ and -4.88 .

FABHRMS $[\mathrm{M}+1]^{+}$calculated for $\mathrm{C}_{25} \mathrm{H}_{40} \mathrm{O}_{4} \mathrm{Si}: 433.2774$, observed: 433.2790 . $[\alpha]_{\mathbf{D}}{ }^{20} \quad\left(\mathrm{c} 0.57, \mathrm{CHCl}_{3}\right)+2.4$

Fragment 4. A slurry of ketone $24(53 \mathrm{mg}, 0.13 \mathrm{mmol})$ and $\mathrm{CeCl}_{3}(31 \mathrm{mg}, 0.13 \mathrm{mmol})$ in $\mathrm{MeOH}(1.3 \mathrm{ml})$ was stirred and cooled to $-78{ }^{\circ} \mathrm{C}$. $\mathrm{NaBH}_{4}(5 \mathrm{mg}, 0.13 \mathrm{mmol})$ was added slowly. The solution was stirred for $15 \mathrm{~min}$., after which it was warmed to $0{ }^{\circ} \mathrm{C}$, and water $(2 \mathrm{ml})$ was added. The reaction mixture was warmed to room temperature and quenched with water $(2 \mathrm{ml})$. Then EtOAc $(2 \mathrm{ml})$ was added. The aqueous layer was extracted with EtOAc $(2 \times 2 \mathrm{ml})$. The organic layers were combined, washed with water $(3 \mathrm{ml})$, brine $(3 \mathrm{ml})$, and dried $\left(\mathrm{Na}_{2} \mathrm{SO}_{4}\right)$, filtered and evaporated under reduced pressure. The residue was purified by flash chromatography to afford alcohol (52 $\mathrm{mg}, 96 \%)$ as a clear colorless oil.

FT-IR $\quad v_{\max }\left(\right.$ neat, $\left.\mathrm{cm}^{-1}\right)$ 3509, 2930, 2856.

${ }^{1}$ H NMR $\quad \delta_{\mathrm{H}}\left(500 \mathrm{MHz} ; \mathrm{CDCl}_{3}\right) 7.26(2 \mathrm{H}, \mathrm{d}, J$ 8.5), $6.87(2 \mathrm{H}, \mathrm{d}, J$ 8.5), $5.69(1 \mathrm{H}$, dt, $J$ 7.4, 15.4), $5.47(1 \mathrm{H}, \mathrm{dd}, J 6.6$ and 15.4), $4.82(1 \mathrm{H}, \mathrm{s}), 4.76(1 \mathrm{H}, \mathrm{s})$, $4.42(3 \mathrm{H}, \mathrm{s}), 3.94(1 \mathrm{H}, \mathrm{m}), 3.81(3 \mathrm{H}, \mathrm{s}), 3.72(2 \mathrm{H}, \mathrm{m}), 3.45(2 \mathrm{H}, \mathrm{t}, J$ 6.8), $2.41(1 \mathrm{H}, \mathrm{d}, J 6.8), 2.38(1 \mathrm{H}, \mathrm{d}, J 7.4), 1.74(3 \mathrm{H}, \mathrm{s}), 1.70(2 \mathrm{H}, \mathrm{m})$, $0.83(9 \mathrm{H}, \mathrm{s}), 0.01(3 \mathrm{H}, \mathrm{s})$ and $0.00(3 \mathrm{H}, \mathrm{s})$.

${ }^{13}$ C NMR $\quad \delta_{\mathrm{c}}\left(125 \mathrm{MHz} ; \mathrm{CDCl}_{3}\right) 159.15,141.95,131.81,131.03,130.78,130.72$, $129.24,113.78,73.32,72.56,72.46,69.74,55.29,42.31,29.72,29.42$, $25.89,18.18,-4.02$ and -4.53 .

FABHRMS $[\mathrm{M}+1]^{+}$calculated for $\mathrm{C}_{25} \mathrm{H}_{42} \mathrm{O}_{4} \mathrm{Si}$ : 435.2931 , observed: 435.2907.

$[\alpha]_{\mathbf{D}}{ }^{20} \quad\left(\mathrm{c} 0.52, \mathrm{CHCl}_{3}\right)+1.6$

A solution of alcohol $(85 \mathrm{mg}, 0.203 \mathrm{mmol})$ in $\mathrm{CH}_{2} \mathrm{Cl}_{2}(2.0 \mathrm{ml})$ was cooled to $0{ }^{\circ} \mathrm{C}$. To this solution was added 2,6-lutidine $(94 \mu \mathrm{l}, 0.812 \mathrm{mmol})$ and triisopropylsilyl triflate (108 $\mu \mathrm{l}, 0.41 \mathrm{mmol})$. The reaction was warmed to $7{ }^{\circ} \mathrm{C}$, where it was held for $18 \mathrm{~h}$. The reaction was quenched with aqueous saturated $\mathrm{NH}_{4} \mathrm{Cl}(2 \mathrm{ml})$, and the aqueous layer was 
extracted with $\mathrm{CH}_{2} \mathrm{Cl}_{2}(2 \times 2.0 \mathrm{ml})$. The organic layers were combined, dried $\left(\mathrm{Na}_{2} \mathrm{SO}_{4}\right)$, filtered and evaporated under reduced pressure. The residue was purified by flash chromatography to afford Fragment 4 (98 mg, 82\%) as a clear viscous oil.

FT-IR $\quad v_{\max }\left(\right.$ neat, $\left.\mathrm{cm}^{-1}\right) 2943,2865$.

${ }^{1}$ H NMR $\quad \delta_{\mathrm{H}}\left(500 \mathrm{MHz}, \mathrm{CDCl}_{3}\right) 7.28(2 \mathrm{H}, \mathrm{d}, J 8.3), 6.89(2 \mathrm{H}, \mathrm{d}, J$ 8.4), $5.63(1 \mathrm{H}$, $\mathrm{dt}, J 16.8$ and 15.8), $5.53(1 \mathrm{H}, \mathrm{dd}, J 5.6$ and 15.8$), 4.77(1 \mathrm{H}, \mathrm{s}), 4.71(1$ $\mathrm{H}, \mathrm{s}), 4.44(2 \mathrm{H}, \mathrm{s}), 4.23(1 \mathrm{H}, \mathrm{t}, J 5.2), 3.81(3 \mathrm{H}, \mathrm{s}), 3.47(2 \mathrm{H}, \mathrm{t}, J 6.5)$, $2.37(1 \mathrm{H}, \mathrm{d}, J 13.6), 2.15(5 \mathrm{H}, \mathrm{m}), 1.91(1 \mathrm{H}, \mathrm{dd}, J 11.7$ and 13.6), 1.69 $(3 \mathrm{H}, \mathrm{s}), 1.07(21 \mathrm{H}, \mathrm{s}), 0.88(9 \mathrm{H}, \mathrm{s}), 0.04(3 \mathrm{H}, \mathrm{s})$ and $0.01(3 \mathrm{H}, \mathrm{s})$.

${ }^{13} \mathrm{C}$ NMR $\quad \delta_{\mathrm{c}}\left(125 \mathrm{MHz} ; \mathrm{CDCl}_{3}\right) 159.14,143.39,131.28,130.78,129.26,129.09$, $113.79,112.85,75.35,74.16,72.68,69.68,60.41,55.28,39.54,29.50$, $29.06,25.93,22.78,18.10,12.30,-4.23$ and -4.54 .

FABHRMS $[\mathrm{M}+\mathrm{Na}]^{+}$calculated for $\mathrm{C}_{34} \mathrm{H}_{62} \mathrm{O}_{4} \mathrm{Si}_{2}: 613.4060$, observed: 613.4066 . $[\alpha]_{\mathbf{D}}{ }^{20} \quad\left(\mathrm{c} 0.27, \mathrm{CHCl}_{3}\right)+7.0$

Compound 26. Styrene $(0.229 \mathrm{ml}, 2 \mathrm{mmol})$ in $\mathrm{THF}(10 \mathrm{ml})$ at $0{ }^{\circ} \mathrm{C}$ was treated with 9 BBN-dimer (488 mg, $2 \mathrm{mmol}$ ) in THF (4 ml), and warmed to room temperature. Overall concentration is $0.14 \mathrm{M}$. It was stirred for $4 \mathrm{~h}$. Another flask was charged with acetate 18 (5 mg, $8.6 \mu \mathrm{mol}), \mathrm{Pd}(\mathrm{dppf}) \mathrm{Cl}_{2}(0.7 \mathrm{mg}, 0.86 \mu \mathrm{mol})$ and $\mathrm{K}_{3} \mathrm{PO}_{4}(2.7 \mathrm{mg}, 12.9 \mu \mathrm{mol})$. THF $(0.2 \mathrm{ml})$ and DMF $(0.1 \mathrm{ml})$ was added, followed by borane $(8.5 \mu \mathrm{l}, 12.9 \mu \mathrm{mol})$ and $\mathrm{H}_{2} \mathrm{O}$ ( $0.43 \mathrm{mmol}, 7.74 \mu \mathrm{l}$, an aliquot was taken from the $0.14 \mathrm{M}$ solution in THF prepared before). The reddish solution was heated to $65^{\circ} \mathrm{C}$ for $14 \mathrm{~h}$ during which it turned black. It was cooled to room temperature, diluted with $\mathrm{Et}_{2} \mathrm{O}$, and partitioned between aqueous saturated $\mathrm{NH}_{4} \mathrm{Cl}(2 \mathrm{ml})$. The aqueous layer was extracted with $\mathrm{Et}_{2} \mathrm{O}(2 \times 2.0 \mathrm{ml})$. The organic layers were combined, washed with brine $(5 \mathrm{~m})$, dried $\left(\mathrm{Na}_{2} \mathrm{SO}_{4}\right)$, filtered and evaporated under reduced pressure. The residue was purified by preparative thin-layer chromatography (25\% EtOAc/hexane) to afford 26 (2.5 mg, $4.04 \mu \mathrm{l}, 47 \%)$ as an oil.

FT-IR $\quad v_{\max } 2957,2930,2857,2362$ and 2337.

${ }^{1} \mathbf{H}$ NMR $\quad \delta_{\mathrm{H}}\left(500 \mathrm{MHz} ; \mathrm{CDCl}_{3}\right) 7.58(4 \mathrm{H}, \mathrm{m}), 7.27(6 \mathrm{H}, \mathrm{m}), 7.19(5 \mathrm{H}, \mathrm{m}), 7.09(2$ H, d, J 8.7), 6.76 (2 H, d, J 8.7), $5.73(1 \mathrm{H}, \mathrm{s}), 4.94(1 \mathrm{H}, \mathrm{br} \mathrm{s}), 4.67(1 \mathrm{H}$, 
s), 4.08 (1 H, d, J 11.0), 3.97 (1 H, d, J 11.0), 3.71 (3 H, s), 3.63 (2 H, m), $2.57(2 \mathrm{H}, \mathrm{m}), 2.28(2 \mathrm{H}, \mathrm{m}), 1.96(2 \mathrm{H}, \mathrm{m}), 1.60(3 \mathrm{H}, \mathrm{d}, J 0.9), 1.46(3 \mathrm{H}$, s) and $0.96(9 \mathrm{H}, \mathrm{s})$.

${ }^{13} \mathbf{C ~ N M R} \quad \delta_{\mathrm{c}}\left(125 \mathrm{MHz} ; \mathrm{CDCl}_{3}\right) 158.82,141.88,140.44,136.23,135.58,133.96$, $133.91,129.56,129.55,128.79,128.38,127.56,126.49,125.22,113.91$, 79.36, 63.68, 60.61, 55.31, 41.39, 39.52, 34.85, 32.32, 30.01, 28.89, 26.89, $22.54,19.14,15.86$ and 13.91.

MALDI $\quad m / z 641.5\left(\left(\mathrm{M}^{+}+\mathrm{Na}, 100 \%\right), \mathrm{C}_{41} \mathrm{H}_{50} \mathrm{O}_{3} \mathrm{SiNa}\right.$ requires 641.3

$[\alpha]_{\mathrm{D}}^{20} \quad\left(\mathrm{c} 0.12, \mathrm{CHCl}_{3}\right)+3.0$

\section{Stereochemical assignment by NOE experiment}
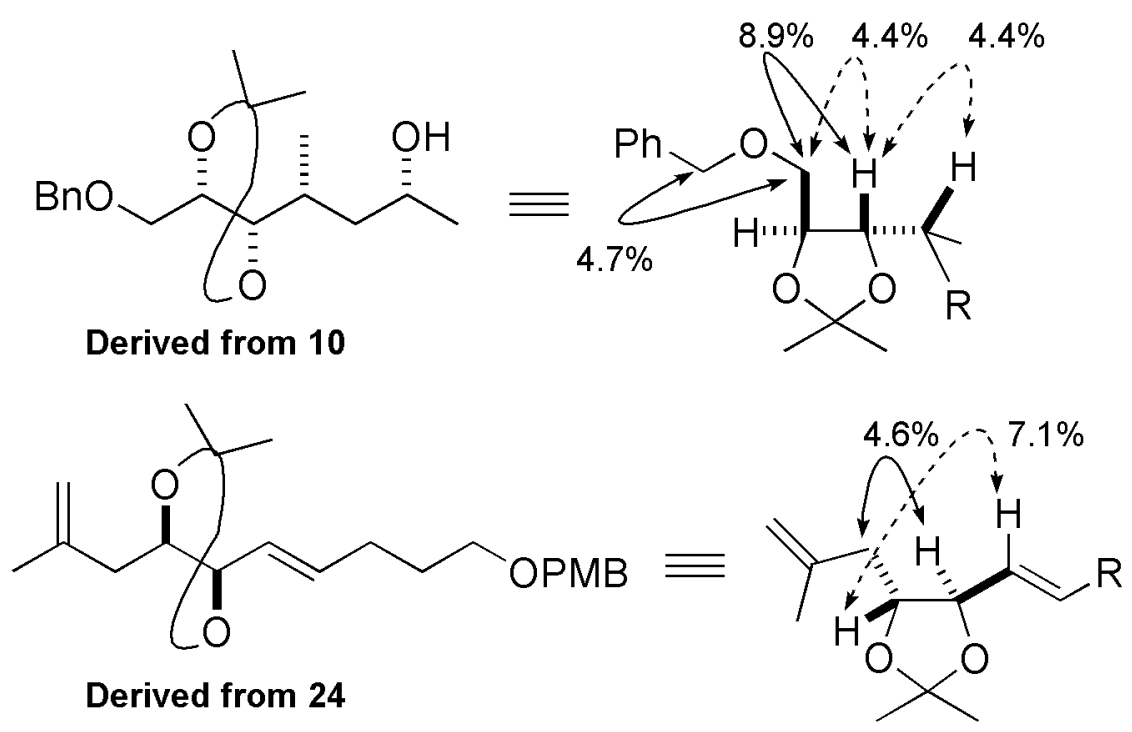


\section{Short text for the Table of contents}

The preparation of three fragments for the total synthesis of amphidinolide B1 has been described. The C16 stereochemistry was set by asymmetric allylic alkylation, C21 \& C25 stereogenic centers by an enantioselective/diastereoselective double allylation reaction and the C9 stereochemistry by an asymmetric heteroene reaction. A differentially substituted stereodefined 1,3-diene iodide was synthesized by iodide mediated $\mathrm{S}_{\mathrm{N}} 2^{\prime}$ reaction. A novel stereoselective method to assemble a 1,3-diene by coupling an allenic acetate and $(B)$-alkylborane is also reported.

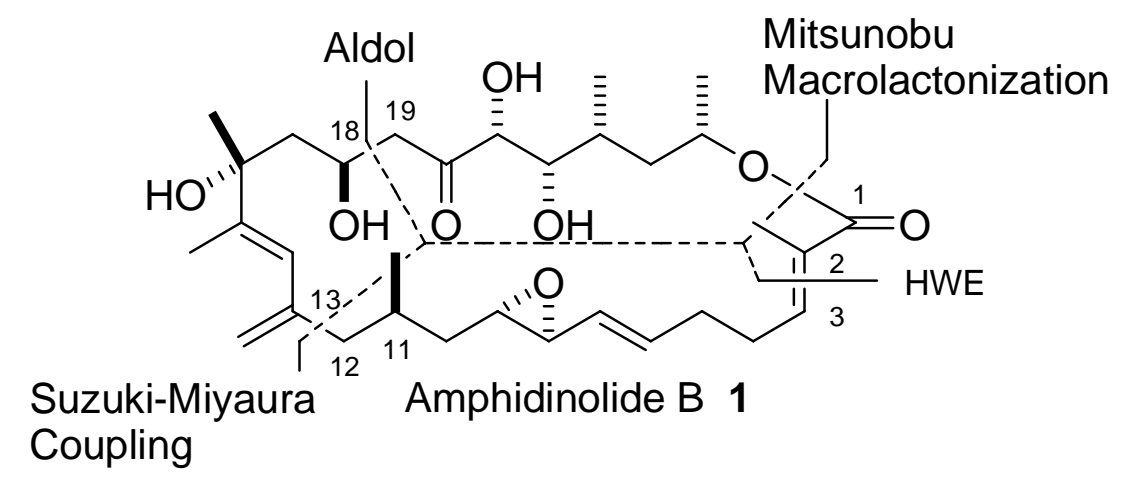

Key words: Asymmetic Alkylation, Asymmetric Synthesis, Anti-cancer Agents, Amphidinolide B1, Partial Synthesis. 